\title{
Neuronal distribution in the putamen in Huntington's disease
}

\author{
RAC ROOS, ${ }^{*}$ JFM PRUYT, ${ }^{*}$ J de VRIES, ${ }^{*}$ GThAM BOTS $\dagger$ \\ From the Departments of Neurology* and Pathology, $\dagger$ University Hospital, Leiden, The Netherlands
}

SUMMARY The numbers of neurons were counted in the ventral and dorsal anterior and ventral and dorsal posterior part of the putamen of 11 Huntington's disease and nine control patients. The process of neuronal cell loss in Huntington's disease proved to be unevenly spread throughout the putamen; the ventral anterior part was relatively spared as compared with the other parts of the putamen. A significantly higher number of neurons was found in the ventral part of the putamen in the controls.

The clinical and neuropathological findings in Huntington's disease are well-known. ${ }^{2}$ The main morphological abnormalities are found in the striatum and frontal cortex, although other parts of the central nervous system are involved as well. ${ }^{3}$ The microscopical findings consist of neuronal loss and astrogliosis, affecting the caudate nucleus and putamen equally. In coronal sections, only minor changes have been described in the ventral-anterior part of the striatum, where the caudate nucleus and putamen fuse. ${ }^{4}$ It has been proposed that the ventral part of the striatum, including the nucleus accumbens, plays a decisive part in the initiation of movements, activated by emotion, whereas the dorsal part of the striatum preferentially subserves cognitively activated movements. ${ }^{5}$ On such a basis, the ventral striatum is to be interpreted as a functional unit, without histological borders. Therefore, we investigated the ventral-anterior part of the putamen in Huntington's disease, in comparison to the dorsal and posterior parts of the putamen.

\section{Material and methods}

The brains of 11 patients with clinically, genetically and neuropathologically proven Huntington's disease and nine control patients were examined. The clinical data are summarised in tables 1 and 2. The Huntington's disease and control necropsies were performed within 6 and 24 hours after death, respectively. The brains were fixed in

Address for reprint requests: Dr RAC Roos, Department of Neurology, University Hospital, Rijnsburgerweg 10, 2333 AA Leiden, The Netherlands.

Received 14 August 1984. Accepted 27 September 1984 phosphate-buffered formalin (4\%), and were cut in frontal $\stackrel{\omega}{\Omega}$ sections. Four putaminal areas, namely the ventral and dorsal parts in the anterior and posterior part were investigated (figs $1 \mathrm{~A}$ and $\mathrm{B}$ ).

The anterior part of the putamen was defined as its ared anterior to a coronal plane through the anterior commi sure. The posterior area of the putamen was defined lying caudally to the plane through the anterior commis sure, and lateral to the thalamus. In all areas, neurons were counted in $7 \mu$ sections in 10 adjacent fields at $\overline{9}$ magnification of $400 \times$ (surface area of $0.073 \mathrm{~mm}^{2}$ ). Ong those neurons were counted that met the following criterizu the nucleus contained a nucleolus; the cytoplasm showeda. $\overrightarrow{0}$ finely granular material and was clearly discernible from of

Table 1 Clinical data of 11 patients with Huntington's disease

\begin{tabular}{ll} 
Huntington's disease: & $\begin{array}{l}11 \text { cases }(3 \text { men and } 8 \text { women, including } \\
1 \text { juvenile })\end{array}$ \\
$\begin{array}{l}\text { Mean age at onset: } \\
\text { Mean duration of }\end{array}$ & $\begin{array}{l}10.6 \text { years }(29-59 \text { years; juvenile } 7 \mathrm{yr}) \\
\text { illness: }\end{array}$ \\
$\begin{array}{l}\text { Mean age at death: } \\
\text { Cause of death: }\end{array}$ & $\begin{array}{l}52 \text { years }(36-73 \text { years; juvenile case } 11 \mathrm{yr}) \\
\text { suffocation } \\
\text { bronchopneumonia } \\
1060 \mathrm{~g}(780-1240 \mathrm{~g})\end{array}$ \\
$\begin{array}{l}\text { Mean brain weight: } \\
(7 \text { cases) }\end{array}$ & 11 \\
\hline
\end{tabular}

Table 2 Clinical data of nine control patients

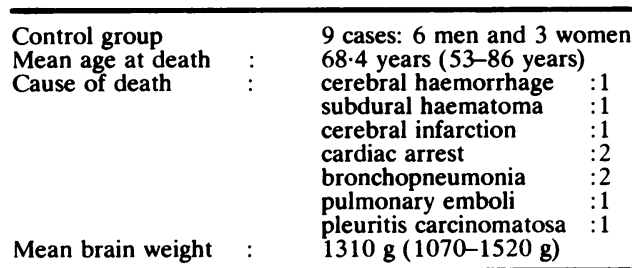


A

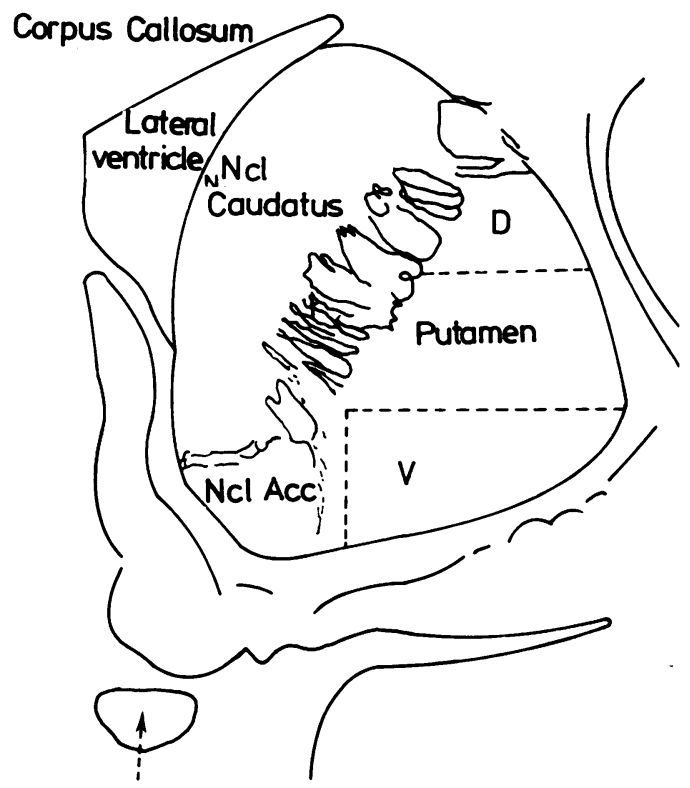

B

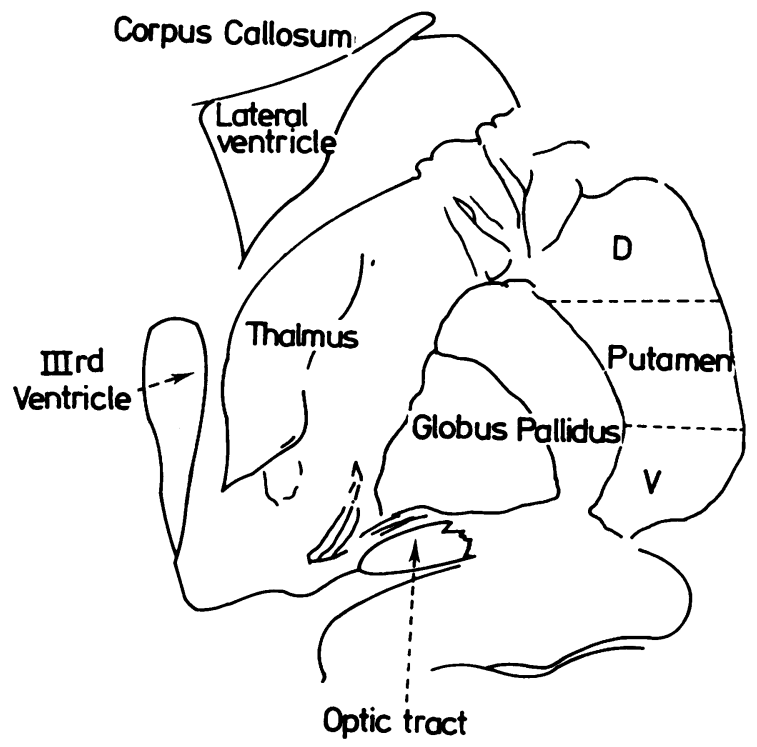

Optic Nerve

Fig 1 The ventral $(V)$ and dorsal $(D)$ areas in the anterior $(A)$ and posterior $(B)$ parts of the putamen that were investigated are shown.

the neuropil. Dead neurons, immediately adjacent to vessels, and neurons that could not be identified with certainty were excluded from counting. No discrimination was made between large and small neurons. The cells were counted twice by two independent observers. The Student $t$ test was used for the comparison between the groups, and between the anterior and posterior putaminal parts.

\section{Results}

The results are shown in table 3 and fig 2 . The interrater and intra-rater variability was less than $5 \%$ each.

Marked neuronal loss, of course, was noted in the Huntington brains. In every area, the mean number of neurons differed significantly from the control group ( $p<0.001)$. The loss of neurons in the ventral anterior parts of the Huntington putamen was, however, significantly less marked ( $p<0.001)$, as compared with the other three areas (fig 2). The mean number of neurons in the ventral anterior and ventral posterior parts of the control putamen was significantly higher as compared with the dorsal putaminal parts $(p<0.01$ and $p<0.05$ respectively). In fig 2 the differences between the areas are represented.

\section{Discussion}

The investigation of the normal striatal cytoarchitecture has led to different conclusions. Namba ${ }^{6}$

Table 3 Mean numbers of neurons of the areas studied in the ventral and dorsal part of the anterior and posterior part of the putamen in 11 Huntington's disease (HD) and 9 control patients $(C O)$. The differences between the $H D$ and CO and between the ventral and dorsal areas are given (Student $t$ ).

\begin{tabular}{llllrrr}
\hline & $\begin{array}{l}\text { anterior } \\
\text { ventral }\end{array}$ & $\begin{array}{l}\text { anterior } \\
\text { dorsal }\end{array}$ & & $\begin{array}{l}\text { posterior } \\
\text { ventral }\end{array}$ & \multicolumn{2}{c}{$\begin{array}{l}\text { posterior } \\
\text { dorsal }\end{array}$} \\
\hline HD & $145 \pm 48$ & $40 \pm 21$ & $\mathrm{p}<0.001$ & $35 \pm 15$ & $35 \pm 20$ & NS \\
CO & $351 \pm 30$ & $289 \pm 36$ & $\mathrm{p}<0.01$ & $342 \pm 36$ & $299 \pm 31$ & $\mathrm{p}<0.05$ \\
& $\mathrm{p}<0.001$ & $\mathrm{p}<0.001$ & $\mathrm{p}<0.001$ & $\mathrm{p}<0.001$ & \\
\hline
\end{tabular}




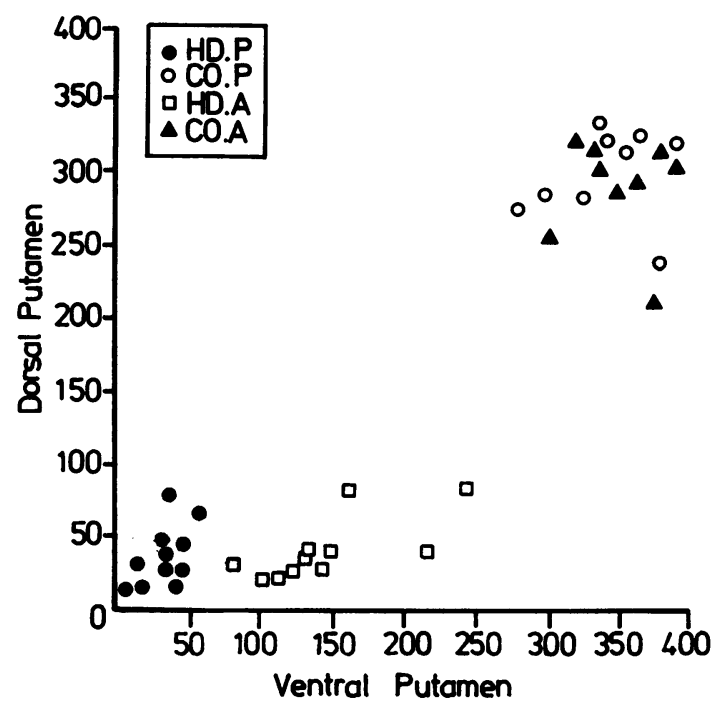

Fig 2 The number of neurons in the anterior $(A)$ and posterior $(P)$ parts of the ventral and dorsal parts of the putamen in 11 Huntington's disease (HD) and 9 control (CO) patients.

described five layers with different cell densities in the caudate nucleus. The densities of large and small neurons appeared higher in the lateral part of the putamen and in the medial caudate nucleus, compared with the medial putamen and lateral caudate nucleus respectively. ${ }^{6-8}$ The normal striatal neuron density showed an increase in antero-posterior direction, ${ }^{8}$ which was not confirmed in our study. We found a higher neuron density in the ventral part of the putamen in controls.

Despite those reports, the striatum, including the nucleus accumbens, is still being regarded as a morphologically rather homogeneous structure. The reported ratios between its large and small neurons vary from $1: 20^{9}$ to $1: 270^{8}$. The divergence in ratios might be explained mainly by difference in counting methods and section thickness. A ratio of $1: 140$ 160 is generally accepted. ${ }^{10}$

In Huntington's disease, the atrophy usually affects the caudate nucleus and the putamen equally." The region where caudate nucleus and putamen fuse ventrally, however, shows only minor changes. ${ }^{4}$ The posterior part of the putamen usually shows degeneration comparable to the anterior dorsal part. ${ }^{72-15}$ The anterior part of the Huntington putamen is relatively less affected. ${ }^{16}$ Our study confirms the earlier unquantified findings. The ventral anterior part of the putamen is relatively spared, as compared with the dorsal anterior and posterior putamen. On the assumption that the initial numeri- cal neuronal distribution in Huntington's putamen iso identical to that of controls, an evenly spread pro- $Z$ cess of cell death can not explain our findings in the $\stackrel{\mathbb{}}{=}$ Huntington putamen. Neuronal loss in the ventralo posterior Huntington putamen seems to be more severe and in the ventral anterior part much less expressed, compared with the dorsal parts. Thesecen findings and the relative sparing of the nucleus $ᄋ$ accumbens $^{1718}$ support the hypothesis of the functional unity of the ventral striatum.

We thank Dr EA van der Velde (Dept of Medical $\stackrel{\overrightarrow{\vec{D}}}{\rightarrow}$ Statistics), Prof Dr GW Bruyn for his criticalo remarks and Mrs I Harlaar-Kiela for typing the manuscript.

\section{References}

' Bruyn GW. Huntington's chorea: historical, clinical and $\vec{\overrightarrow{ }}$ laboratory synopsis. In: PJ Vinken, GW Bruyn edso Handbook of Clinical Neurology, Vol. 6, Amsterdam: North Holland Publishing Company 1968:298-377.

${ }^{2}$ Hayden MR. Huntington's Chorea. Neuropathology. Heidelberg: Springer Verslag, 1981:93-103.

${ }^{3}$ Bruyn GW, Bots GThAM, Dom R. Huntingto chorea: current neuropathological status. In: Chase, NS Wexler, A Barbeau, eds Advances trno $^{N}$ Neurology, Vol. 23, New York: Raven Press, 1979:83-93.

${ }^{4}$ McCaughey WTE. The pathologic spectrum of Huntimton's chorea. J Nerv Ment Dis 1961;133:91-103. 宆

${ }^{5}$ Heimer L, Switzer RD, Hoesen van, GW. Vent丽 $\overrightarrow{0}$ striatum and ventral pallidum components of motor system? Trends in Neurosciences 1982;5:83-7.

- Namba M. Cytoarchitektonische Untersuchung am Striatum. J Hirnforsch 1957;3:24-48.

${ }^{7}$ Brockhaus H. Zur feineren Anatomie des Septum und $\bar{\partial}$ des Striatum. J Psychol Neurol 1942;51:1-56.

${ }^{8}$ Tabuchi K. Cytoarchitektonische Untersuchung des $\stackrel{\circ}{\mathbb{Q}}$ Corpus Striatum beim Menschen. J Hirnforsch 으 1969;11:325-32.

${ }^{9}$ Peele TL. The Neuroanatomic Basis for Clinical Neurol-3 ogy. New York: McGraw Hill, 1961:395-430.

${ }^{10}$ Dom R, Baro F, Bruchner JM. A cytometric study of the putamen in different types of Huntington's chorea. In: A Barbeau, TN Chase, GW Paulson eds Advances in Neurology, Vol. 1, New York: Raven Press,? 1973:369-85.

"Lange H, Thörner G, Hopf A, Schröder KF. Morphometric studies of the neuropathological changes in choreatic diseases. J Neurol Sci 1976;28:401-25.

12 Lewy FH. Zur pathologisch-anatomischen differentialo Diagnose der Paralysis agitans und der Huntingtonschen Chorea. Z Gesamte Neurol Psychiato 1921;73:170-87.

${ }^{13}$ Schroeder K. Zur Klinik und Pathologie der Hunting- $N$ tonischen Krankheit. J Psychol Neurol 1931;43:183-201.

${ }^{14}$ Hallervorden-Giessen J. Huntingtonische Choreacట 
(Chorea chronica progressive hereditaria). In: $\mathrm{O}$ Rubarsch, F Henke, R Rössle (eds). Erkrankungen des Nervensystems I. Handbuch der speziellen pathologischen Anatomie und Histologie, Vol. 13A, Berlin: Springer-Verlag, 1957;793-822.

${ }^{15}$ Forno LS, José C. Huntington's chorea: a pathological study. In: A Barbeau, TN Chase, GW Paulson eds. Advances in Neurology, Vol. 1, New York: Raven Press, 1973:453-70.

${ }^{16}$ Dunlap CB. Pathologic changes in Huntingdon's chorea with special references to the striatum. Arch Neurol Psychiat 1927; 18:867-943.

${ }^{17}$ Uchiyama S, Matsushita M, Kosaka K. Neuronal change in the nucleus accumbens in Huntington's chorea. IXth International Congress of Neuropathology, Vienna. Vienna: Egermann Druckerei Gesellschaft m.b.H. \& Co KG, 1982:260.

${ }^{18}$ Roos RAC, Bots GThAM. Nuclear membrane indentations in Huntington's chorea. J Neurol Sci 1983;61:37-47. 